\title{
أحكام سب الرسول عند القاضي عياض في كتابه "الشفا بتعريف حقوق المصطفى" (دراسة وصفية)

\author{
أمير شاهدين
} \\ جامعة دار السلام كونتور
}

Email:amirsahidin135@gmail.com

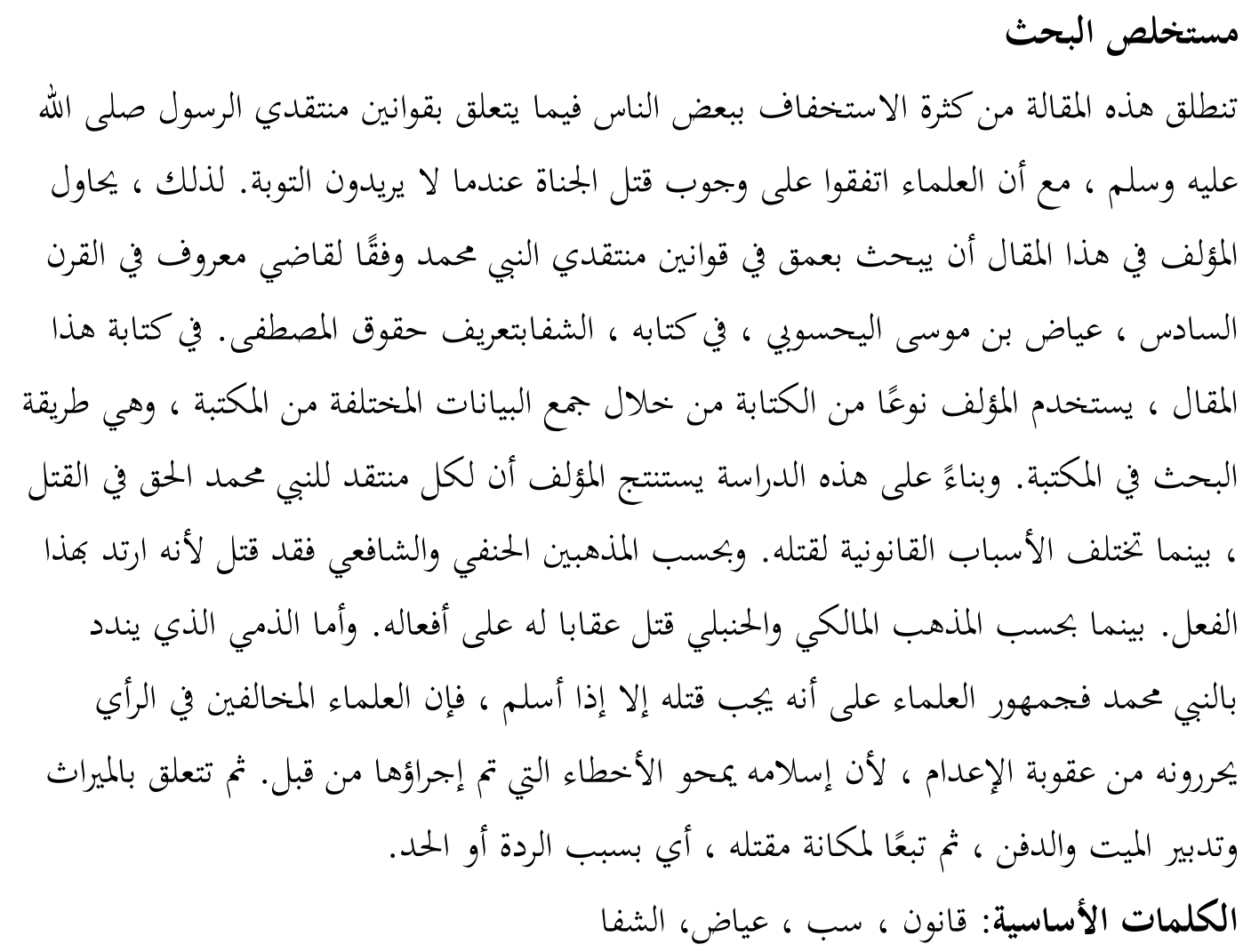

Abstract

This article starts from the many belittlement that some people make regarding the laws for detractors of the Prophet Muhammad, even though the scholars have agreed on the legal obligation to kill the perpetrators when they do not want to repent. So, in this article the author tries to examine more deeply regarding the laws for detractors of the Prophet Muhammad according to a well-known judge in the VI century, Iyad bin Musa alYahsubi, in his book, al-Syifâ fì Ta'rîf Huqûq al-Musthafâ. In writing this article, the author uses a qualitative type of writing by collecting various data from the library, namely the library research method. Based on this study, the author concludes that every detractor of the Prophet Muhammad has the right to be killed, while the legal reasons for his killing have different opinions; according to the Hanafi and Shafi'i schools he was 
أمير شاهدين

killed because he had apostatized with this act; whereas according to the Maliki and Hanbali schools he was killed as punishment al-had for his actions. As for a dzimmi who denounces the Prophet Muhammad, the majority of scholars are of the opinion that he must be killed unless he converts to Islam, the scholars who differ in opinion will free him from the death penalty, because his Islam will erase the mistakes that have been made before. Then related to inheritance, management of corpses and burial, then depending on the status he was killed, namely because of apostasy or al-had.

Keywords: Law, Criticizing, Iyad, al-Syifâ.

\section{Abstrak}

Artikel ini berangkat dari banyaknya peremehan yang dilakukan sebagian masyarakat terkait hukum-hukum bagi pencela Nabi Muhammad, padalah para ulama telah bersepakat tentang keharusan hukum bunuh bagi pelakunya ketika tidak mau bertaubat. Maka, dalam artikel ini penulis mencoba mengkaji lebih dalam berkenaan hukum-hukum bagi pencela Nabi Muhammad menurut seorang hakim terkenal abad ke-VI, Iyad bin Musa al-Yahsubi, dalam kitabnya, al-Syifâ fî Ta'rîf Huqûq al-Musthafâ. Dalam penulisan artikel ini, penulis menggunakan jenis penulisan kualitatif dengan mengumpulkan berbagai data dari perpustakaan, yaitu dengan metode library research. Berdasarkan kajian tersebut, penulis menyimpulkan bahwa setiap pencela Nabi Muhammad berhak untuk dibunuh, adapun sebab hukum bunuhnya para ulama berbeda pendapat; menurut Madzhab Hanafi dan Syafi'i ia dibunuh dikarenakan telah murtad dengan perbuatan tersebut; sedangkan menurut Madzhab Maliki dan Hanbali ia dibunuh sebagai hukuman al-had atas tindakannya. Adapun bagi seorang dzimmi yang mencela Nabi Muhammad, maka jumhur ulama berpendapat akan keharusannya untuk dibunuh kecuali jika ia masuk ke dalam agama Islam, para ulama berselisih pendapat akan terbebasnya dari hukuman mati, tersebab dengan keislamannya akan menghapus kesalahan-kesalahan yang telah diperbuat sebelumnya. Kemudian terkait dengan warisan, pengurusan mayat dan pengkuburannya, maka tergantung dengan status ia dibunuh, yaitu karena murtad atau al-had.

Kata kunci: Hukum, Mencela, Iyad, al-Syifâ.

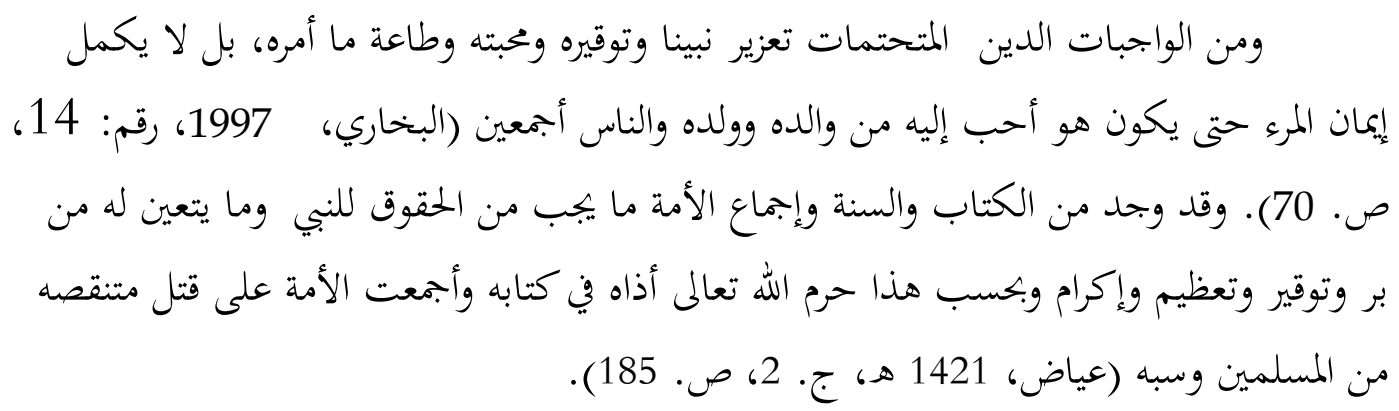




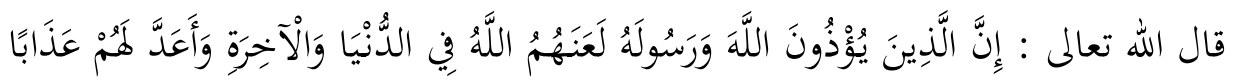

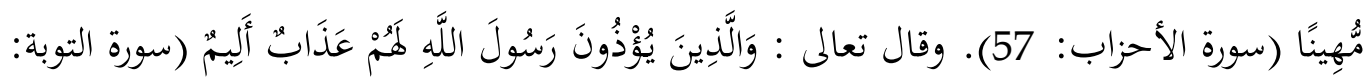

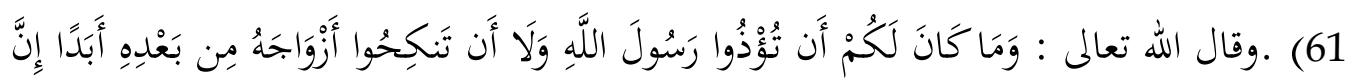

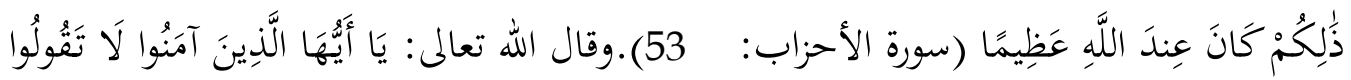

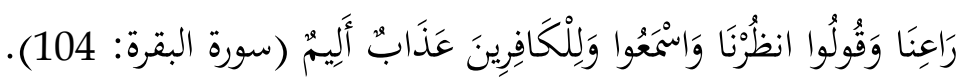

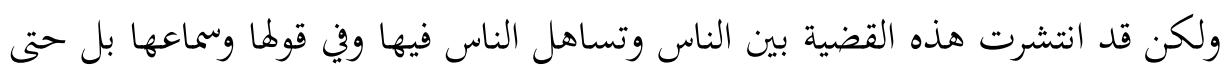

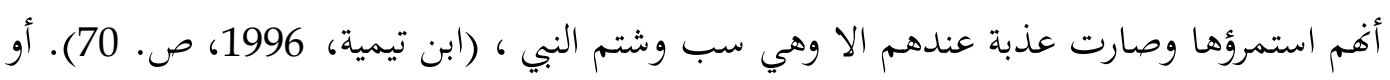

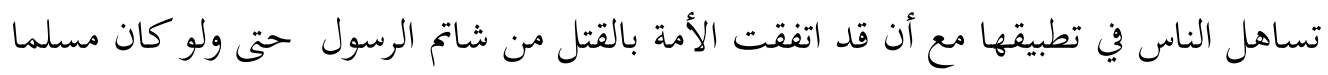

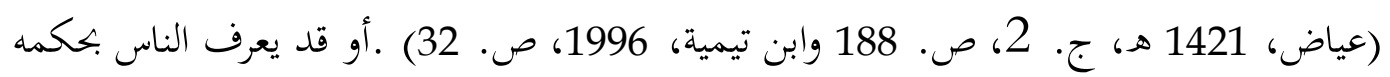

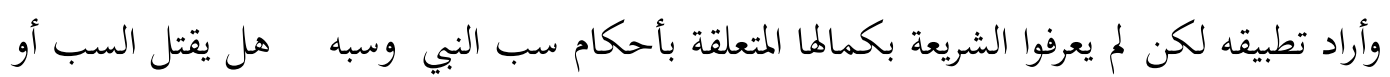
يستتاب أويورث أو يغسل وغيرهم مما يتعلق به.

لقد مرت هذة القضية منذ زمن النبي المى زمننا الان كما روي عن ابن عباسرضي وضي الله عنهما

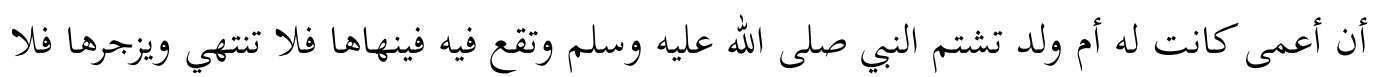

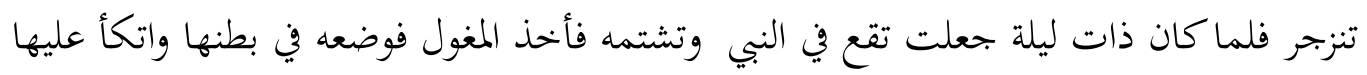

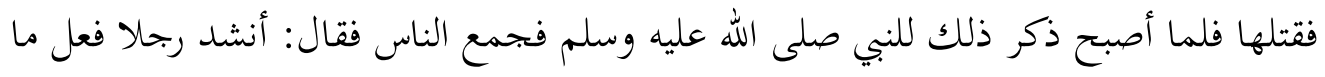

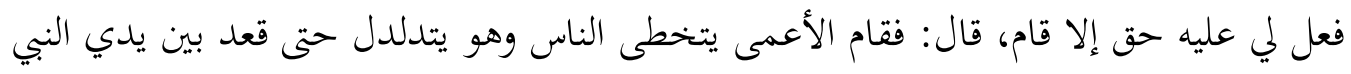

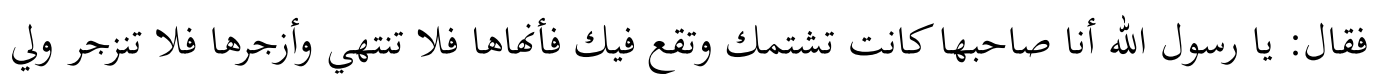

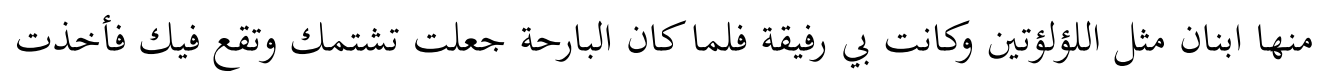

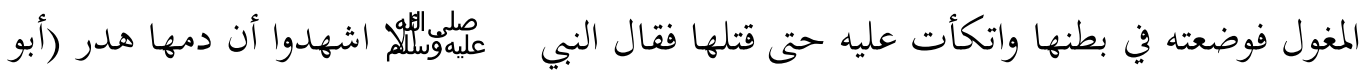
داود، 1998، رقم: 4361، ص. 659).

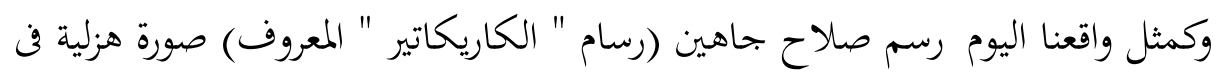

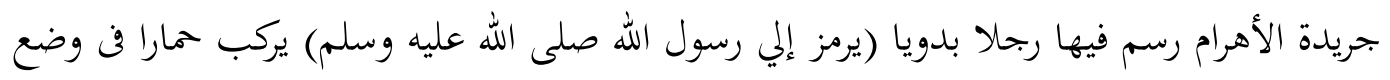

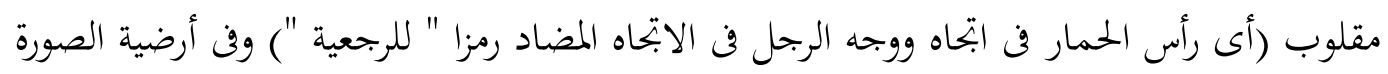

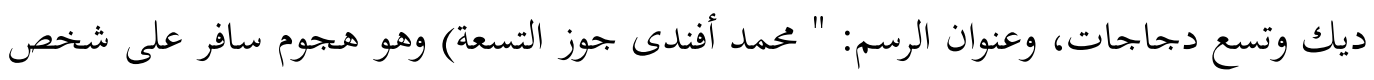

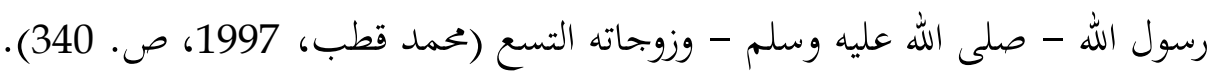


ثم وجدنا في فرنسية (Perancis) من التاريخ 7 كياير 2015 هناك قضية متعجبة يعني قتل بعض المسلمين سب الرسول في المركز ش ارلي هيفدو(charlie hebdo) الذينهم يسبون الرسول برسوم كاريكاتيرية المسيئة لنبي محمد. ( bbc.com, 2015 في تلك القضية اختلف الناس على الطائفتين العظيمين إما ان يوجزه ويعونه وإما ان يمنعه ويلعنه.

لذا في هذا الموضوع، واضح بأن معرفة الأحكام التي تتعلق بسب الرسول مهمة جدا، إذ هي من حصانة لحرمة النبي وحرمة المسلمين عامة. ولهاذ أخذ الباحث هذا الموضوع وقيده من كتاب الشفا بتعريف حقوق المصطفى الذي ألفه القاضى عياض أبي الفضل عياض بن موسى بن عياض

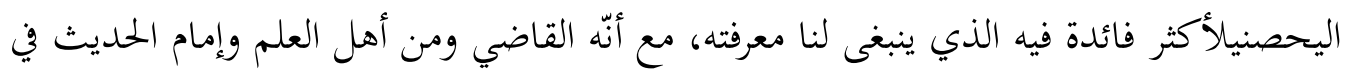

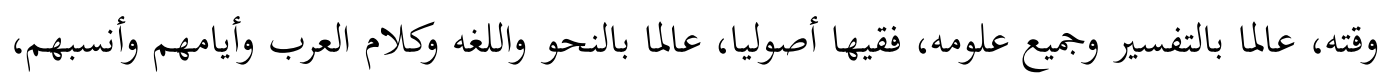
بصيرا بالأحكام، حافظ لمذهب مالك، شاعرا بحيدا، خطيبا بليغا، صبورا حليما جميل العشرة، جوادا سمحا كثير الصدق، دؤوبا علي العمل، صلبا في الحق (فرحون المالكي، ج. 2، ص. 47).

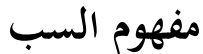
أ. تعريف السب السب

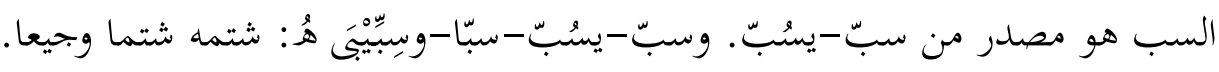

سبّب هُ: بالغ في شتمه. سب مسبة وسبابا هُ: شاتمه. تسب الرجلان: تقاطعا وتشاتما. استبّ القوم: تشاتموا. استبّ له: عرّضه للسبّ وجره إليه. السبّ والسببة والمسبّ والمسبّة: الكثير السبّ. الأسبوبة: ما يدور عليه السبّ والستم.يقال (بينهم أسبوعة يتسبون بها) أي بينهم ما يسبّ به بعضهم بعضا. (المنجد، 1973، ص. 315-315)

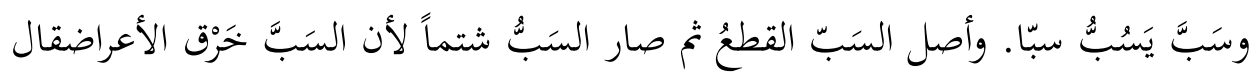
الشاعر :فما كان ذَنْبُ بني مالكٍ ... بأن سُب منهم غلام فَسَب أي شُتم فقَطع. ويُروى: لأن

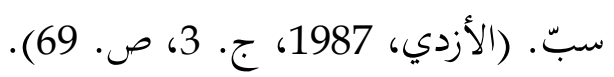

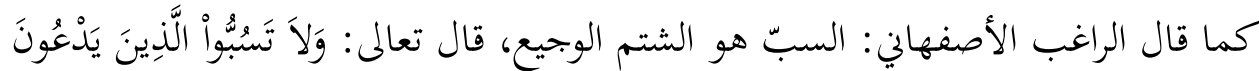

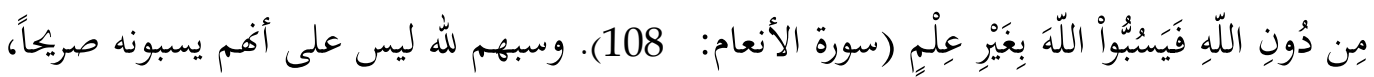
ولكنهم يخوضون في ذكره، فيذكرونه بما لا يليق، ويتمادون في ذلك بالمحادلة فيزدادون في ذكره بما تنزه تعالى عنه. (أبو القاسم، دون السنة، ص. 220). 
وقال ابن تيمية: "السبّ هو الكلام الذي يقصد به الانتقاص والاستخفاف، وهو ما يفهم منه السبّ في عقول الناس على اختلاف اعتقاداتمكاللعن والتقبيح ونحوه، (ابن تيمية، 1996،

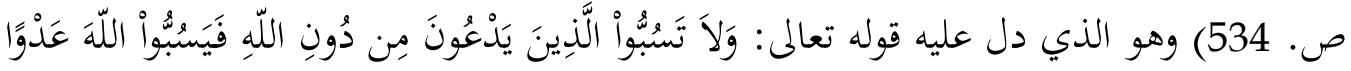

بِغَيْرِ (سورة الأنعام : 108). وقال الحافظ ابن حجر: الشتم هو الوصف بما يقتضي النقص (ابن

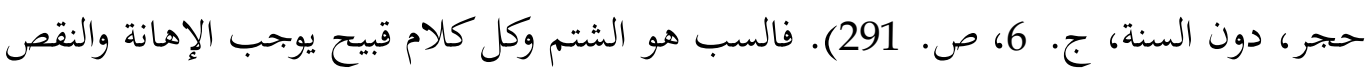
(اللطيف، 1414 هـ، ص. 108).

وقال القاضي عياض: أن جميع من سبّ النبي أو عابه أو ألحق به نقصا في نفسه أو نسبه

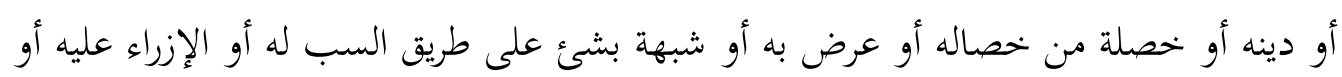
التصغير لشأنه أو الغض منه والعيب له فهو سب له (عياض، 1421، ج. 2، ص. 188). فقال الباحث: بعد أن اطلعنا على هذه الأقوال، وجدنا أن لب معن السب ومفهومه هو: الكلام الذي يقصد به الانتقاص والاستخفاف، وهو ما يفهم منه السبّ في عقول الناس على اختلاف اعتقاداتمكاللعن أو التقبيح أو ألحق به نقصا في نفسه أو نسبه أو دينه أو خصلة من خصاله أو عرض به أو شبهة بشئ على طريق السب له أو الإزراء عليه أو التصغير لشأنه أو الغض منه والعيب له.

ب. الفرق بين السبّ والاستهزاء رأينا بأن السبّ يشبه الاستهزاء لأن كثير من العلماء يستعملون الأدلة في حكم الاستهزاء هي نفس أدلة حكم السب. لكن هناك الفرق. أولا من حيث المعنى: بأن السبّ هو الشتم والوجع أما الاستهزاء هو السخرية و هن الإستخفاف، قال الراغب الأصفهاني:هزؤ : الهزء مزح في خفية وقد يقال لما هو كالمزح...، والاستهزاء ارتياد الهزؤ وإن كان قد يعبر به عن تعاطي الهزؤ ـ (أبو القاسم، دون السنة، ص. 542). قال أبو عبدالرحمن المصري، اعلم أن السب في اللغة: الشتم والقطع والطعن قاله صاحب مختار الصحاح، ومعنى الاستهزاء: السخرية. فالسب والاستهزاء ليس مقتصرا على صيغ معينة، ولا على ألفاظ معينة، بل السب والاستهزاء يكون بكل لفظ يؤدي إلى هذه المعاني .وانتبه رحك الله إلى أن أدلة حكم الاستهزاء هي نفس أدلة حكم السب، لكن السب أشد إثما وشناعة واستكبارا على رب العالمين من الاستهزاء. (المصري، 2006، جه 1. 1، ص. 10. 10. 
ثانيا من باب أولى: أن الاستهزاء بالله وأياته وبرسوله كفر، سواء استحله أو لم يستحله،

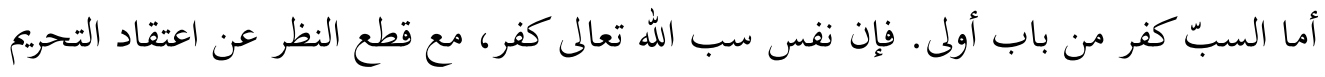

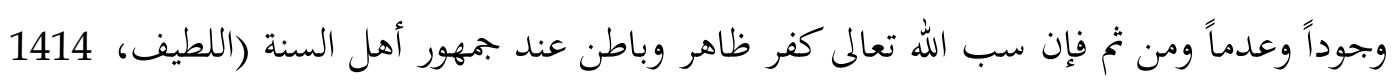
هـ، ص. 109).

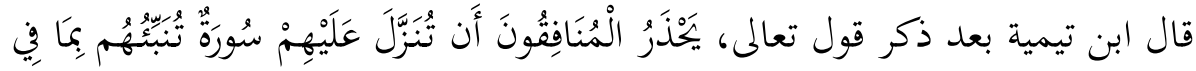

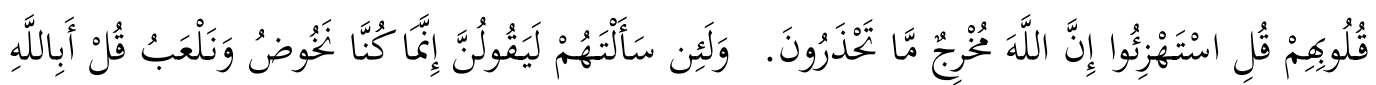

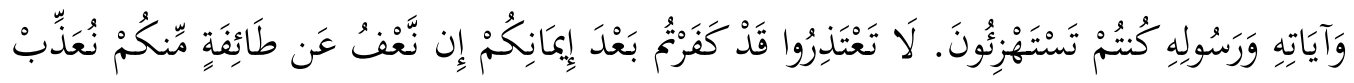

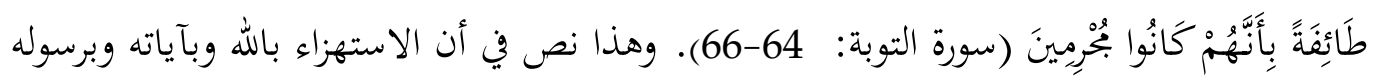

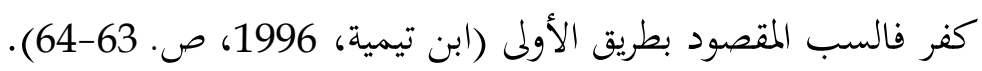

\section{أحكام سب الرسول عند القاضي عياض في كتابه الشفا}

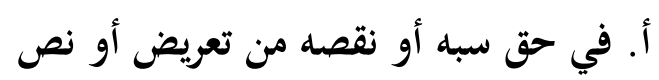

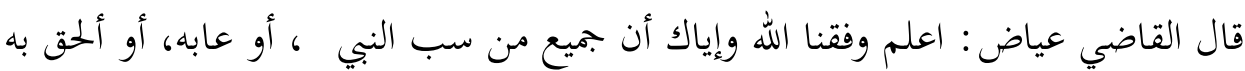

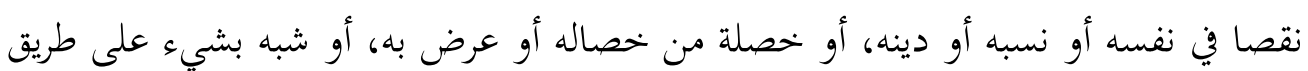

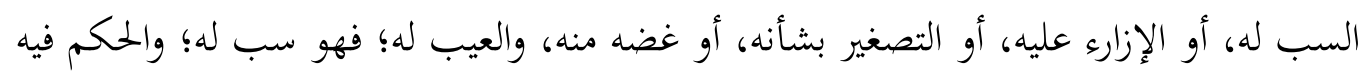

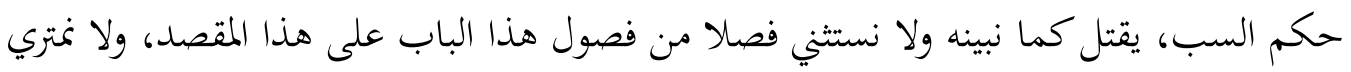

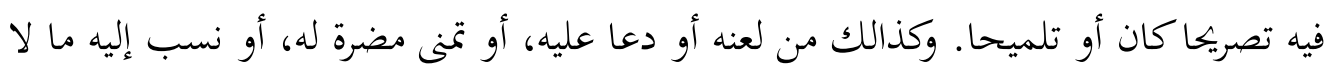

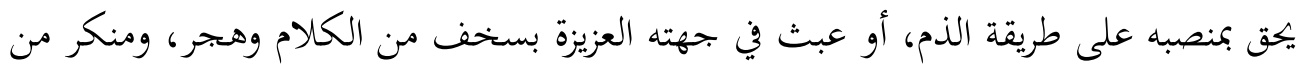

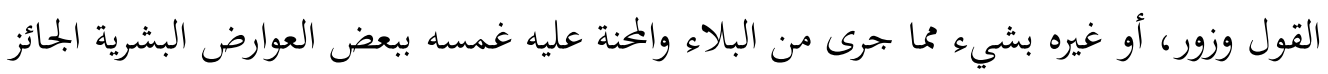

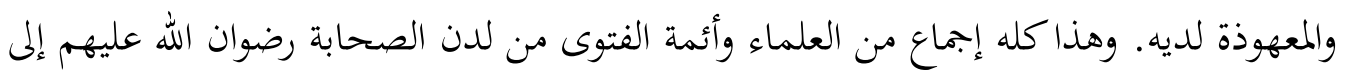

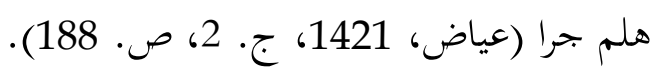

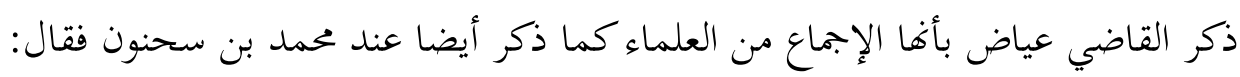

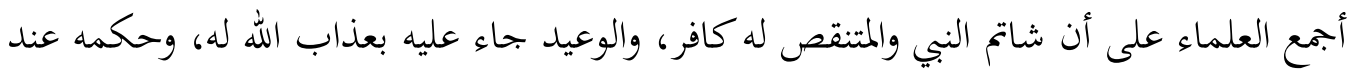

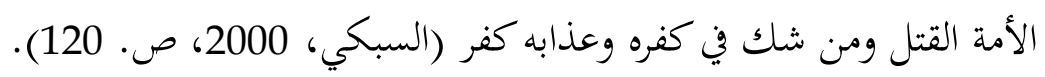

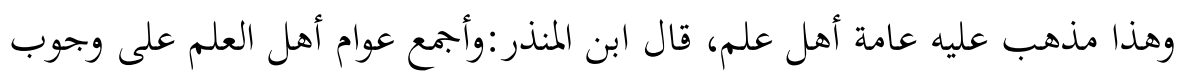

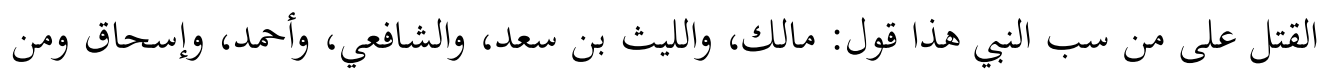

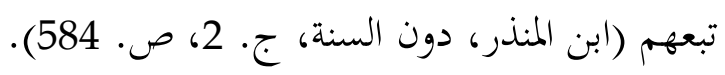




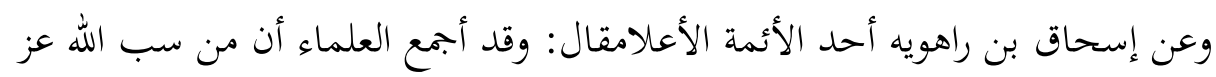

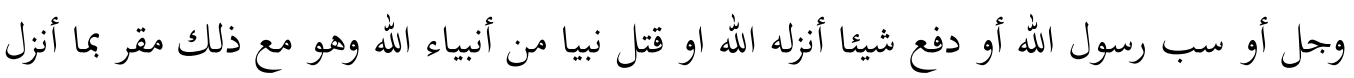

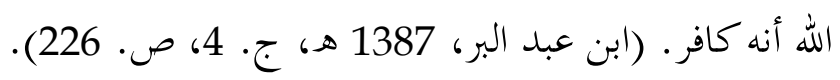

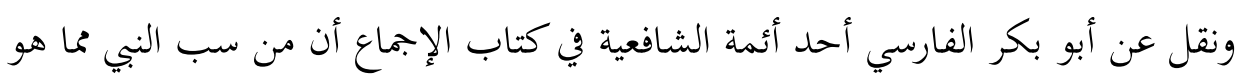

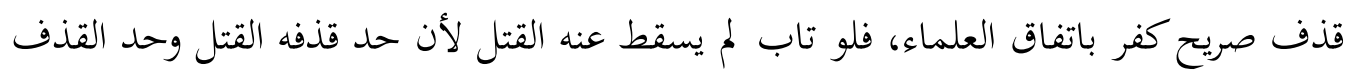

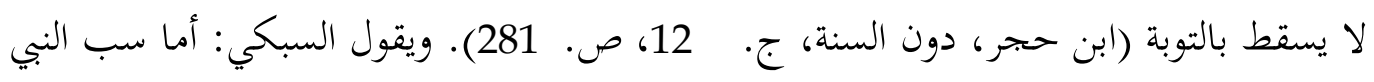

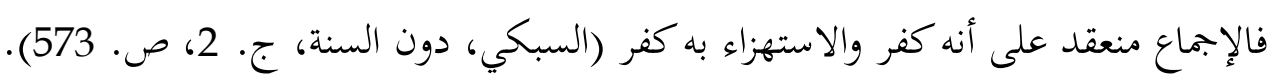

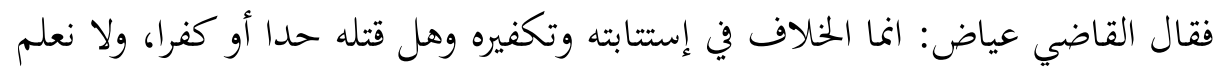
خلاف في استباحة دمه بين علماء الأمصار وسلف الأمة، وقد ذكر غير واحد الإمماع على قتله فيله

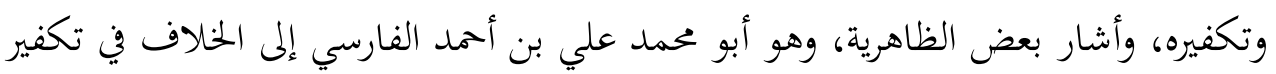

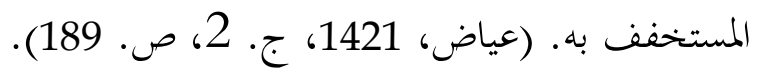

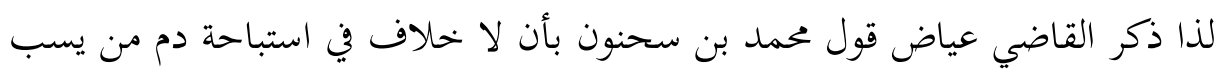

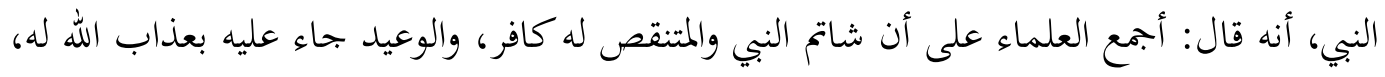

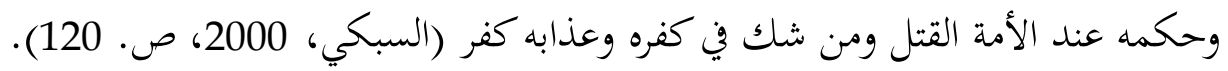

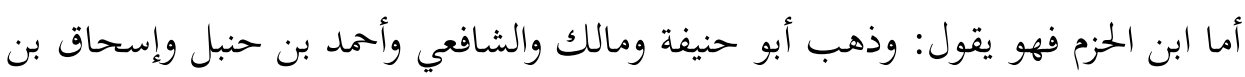

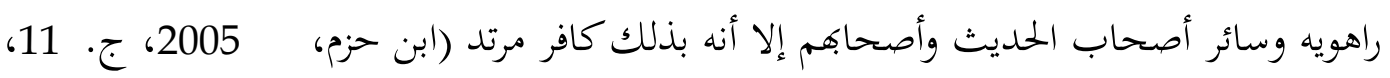

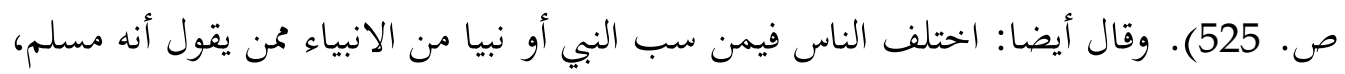

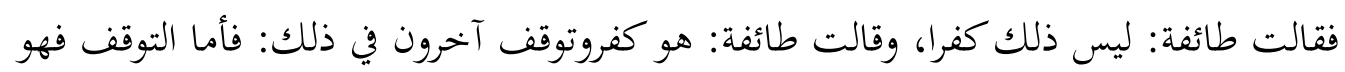

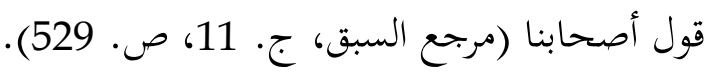

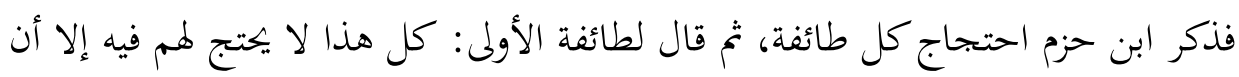

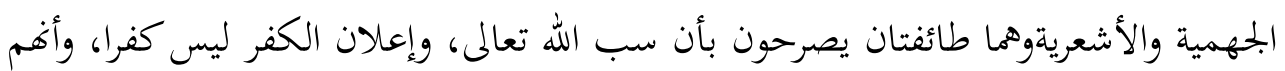

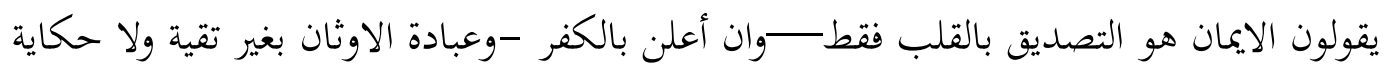

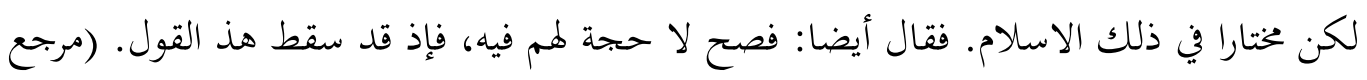
السبق، ج. 11، ص. 523-527)

ثم قال ابن حزم: فصح بهذا كفر من سب البي وأنه عدو لله تعالى. وقال وقال أيضا: فصح بما

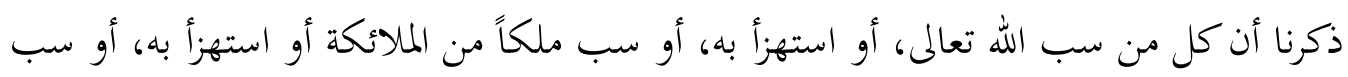


نبياً من الأنبياء أو استهزأ به، أو سب آية من آيات الله تعالى أو استهزأ بها، والشرائع كلها والقرآن

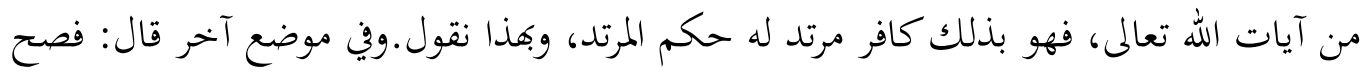

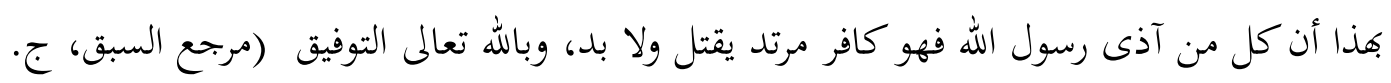
11، ص. 529-530).

لذا ما يظن الباحث أنه أراد نقص الإجماع، وإنما أراد نقل كلام الجهمية والأشاعرة، ورد

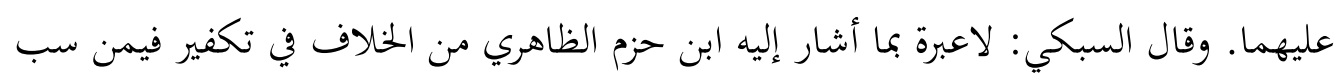

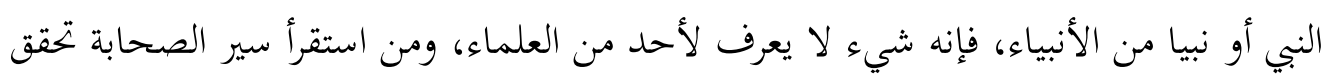

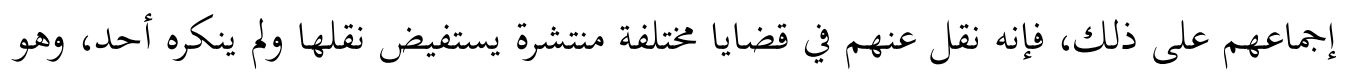

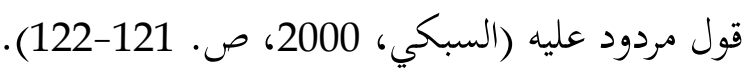
ب. الحجة في الإجاب القتل من سب أو عابه

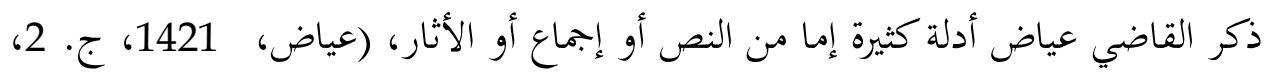

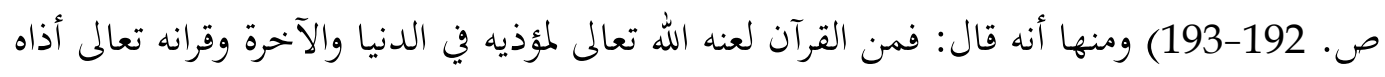

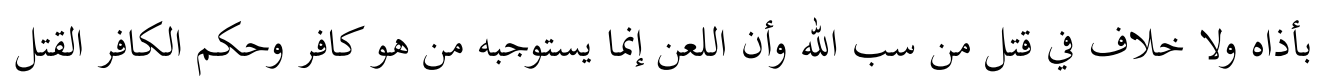

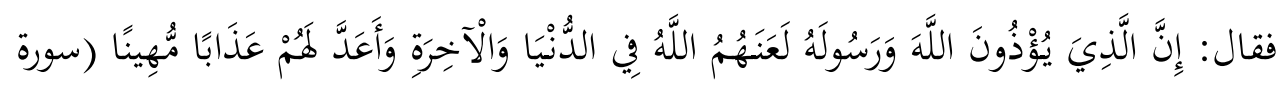
الأحزاب: 57). (57).

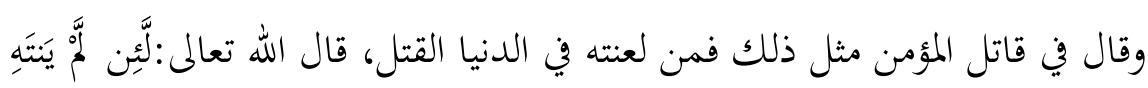

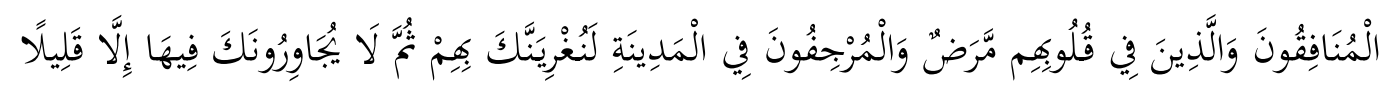

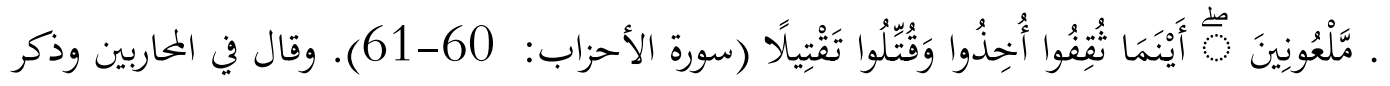

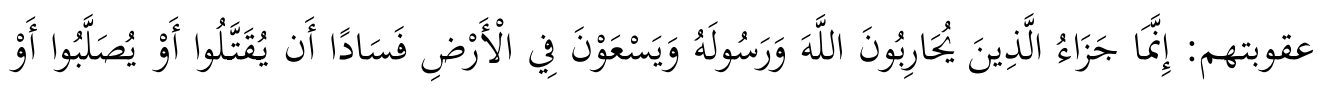

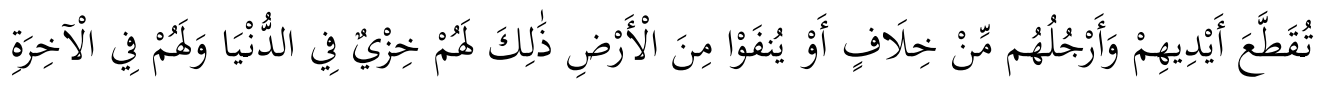

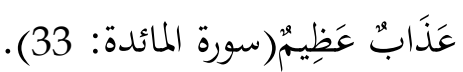

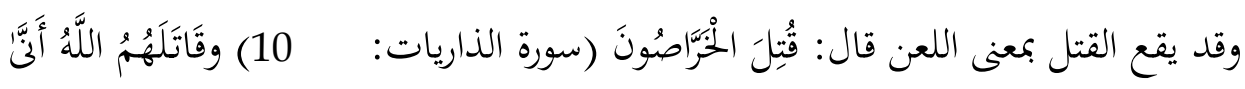

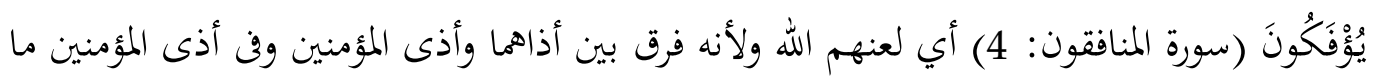

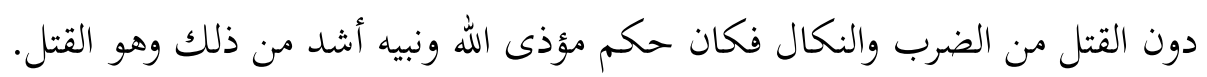

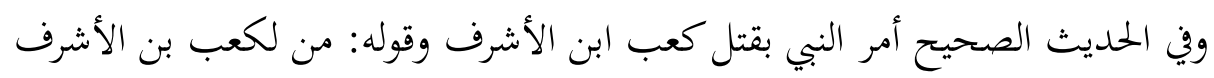

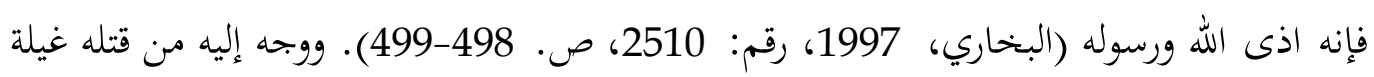


دون دعوة بخلاف غيره من المشركين وعلل بأذاه له فدل أن قتله إياه لغير الإشراك بل للأذى. وكذلك قتل أبا رافع، قال البراء وكان يؤذى رسول الله ويعين عليه. (مرجع السبق، رقم: 4038.834-830. 4040، ص.

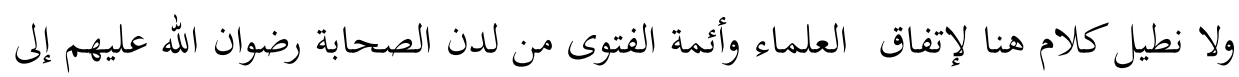

$$
\text { هلم جرا في إجاب القتل من سبه أو عابه. }
$$

\section{ت. في أحكام سبه وشاتمه ومنتنقصه ومؤذيه وعقوبه}

قال القاضي عياض: فاعلم أن مشهور مذهب مالك وأصحابه، وقول السلف وجمهور

العلماء قتله حدا لا كفرا إن أظهر التوبة منه؛ ولهذا لا تقبل عندهم توبته، ولا تنفعه استقالته ولا فيأته كما قدمناه قبل، وحكمه حكم الزنديق، ومسر الكفر في هذا القول؛ وسواء كانت توبته على هذا بعد القدرة عليه والشهادة على قوله، أو جاء تائبا من قبل نفسه لأنه حد لا تسقطه التوبة كسائر الحدود. (عياض، 1421 هـ، ج. 2، ص. 218). وكذلك قال ابن القاسم عن مالك: أن من شتم النبي صلى الله عليه وسلم من المسلمين

قتل ولم يستتب. ونقل عن ابن القاسم في العتبية: أو شتمه أو عابه أو نقصه فإنه يقتل كالزنديق لا تعرف توبته، وقد فرض الله تعزيره وتوقيره. (النفزي، 1999، ج. 14، ص. 526). ونقل عن أبو مصعب وابن أبي أويس: سمعنا مالكا يقول: من سب النبي صلى الله عليه وسلم أو شتمه أو عابه أو تنقصه قتل مسلما كان أو كافرا ولا يستتاب. وكذلك نقل عن قول محمد بن عبد الحكم: أخبرنا أصحاب مالك أنه قال: "من سب النبي صلى الله عليه وسلم أو غيره

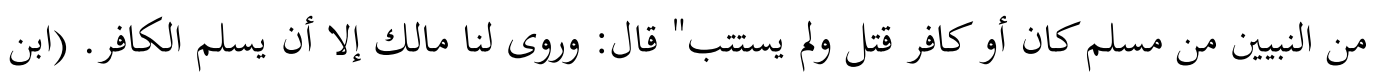
تيمية، 1996، ص. 324).

وقال القاضي عياض: وهذا قول أصبغ، ومسألة سب النبي صلى الله عليه وسلم أقوى، لا يتصور فيها الخلاف على الأصل المتقدم؛ لأنه حق متعلق للنبي صلى الله عليه وسلم ولأمته بسببه لا تسقطه التوبة كسائر حقوق الآدميين، والزنديق إذا تاب بعد القدرة عليه فعند مالك والليث وإسحاق وأحمد لا تقبل توبته، وعند الشافعي تقبل، واختلف فيه عن أبي حنيفة وأبي يوسف، وحكى ابن المنذر عن علي بن أبي طالب رضي الله عنه يستتاب، قال محمد بن سحنون ولم يزل القتل عن المسلم بالتوبة من سبه؛ لأنه لم ينتقل من دين إلى غيره وإنما فعل شيئا حده عندنا القتل لا عفو فيه لأحد كالزنديق؛ لأنه لم ينتفل من ظاهر إلى ظاهر. وقال أيضا، وكلام شيوخنا هؤلاء 
مبني على القول بقتله حدا لا كفرا وهو يحتاج إلى تفصيل، وأما على رواية الوليد ابن مسلم عن

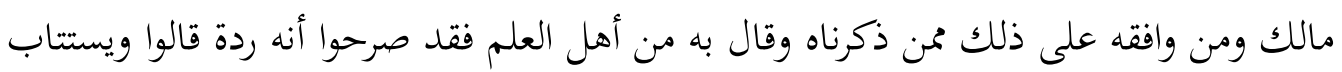

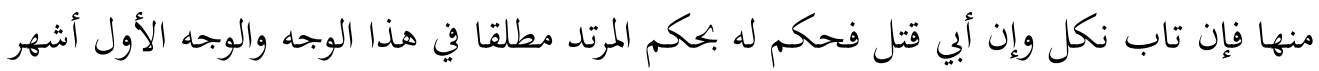

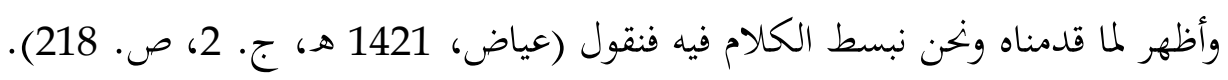

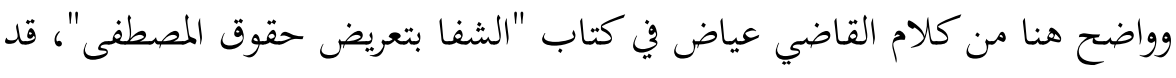

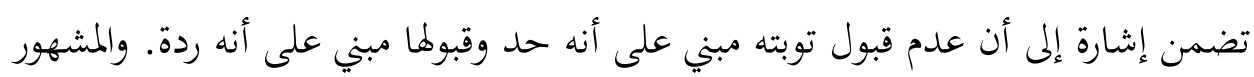

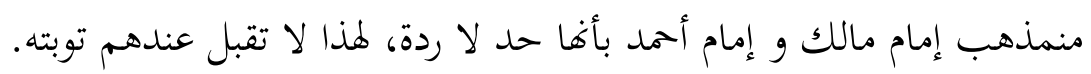

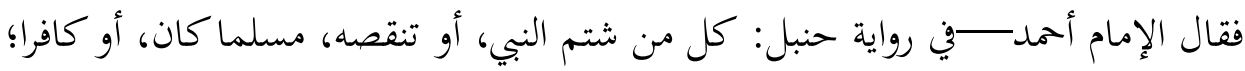

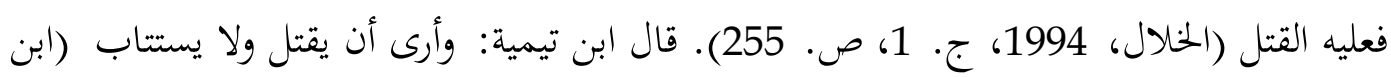

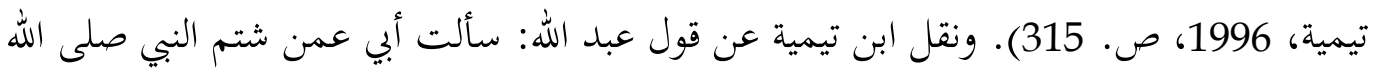

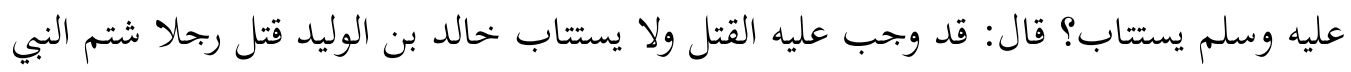

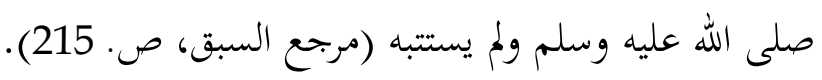

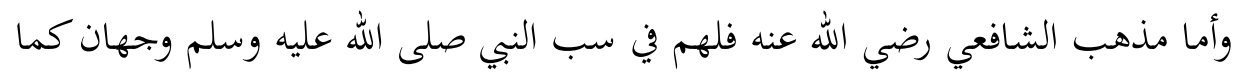

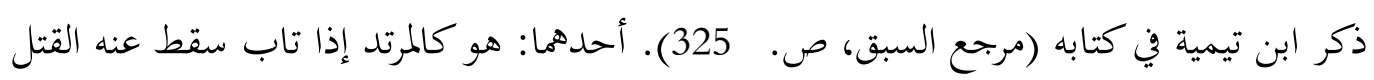

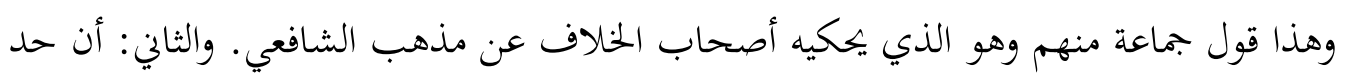

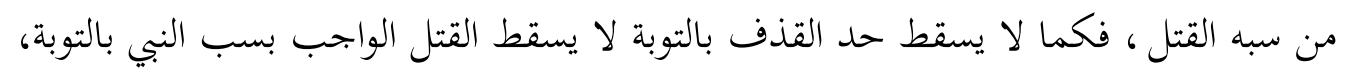

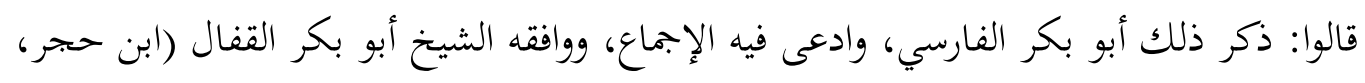

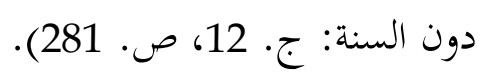

ولكن المشهور على الألسنة عند الحكامـــوما يزالون يمكمون بهـأن مذهب الشافعي

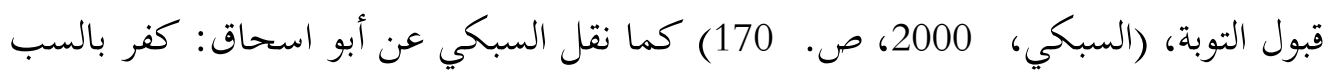

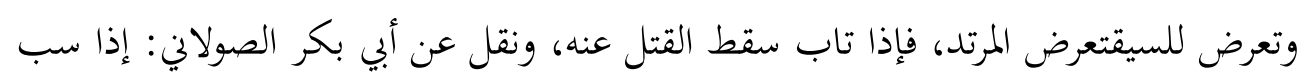

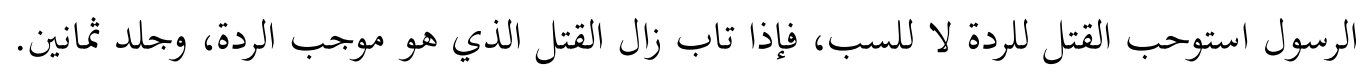

$$
\text { (مرجع السبق، ص. 167). }
$$

ومذهب أبي حنيفة كمذهب الشافعي بأنه يستتاب كما ذكر ابن تيمية، أنه قال: ومذهب

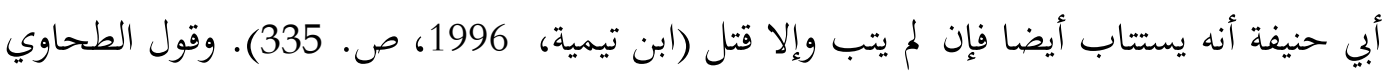

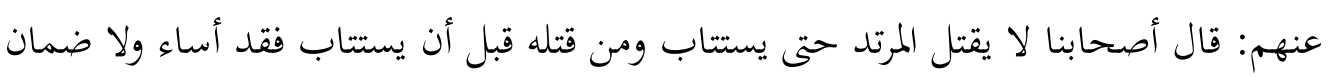


عليه. وذكر بشر بن الوليد عن أبي يوسف في الزنديق الذي يظهر الإسلام قال أبو حنيفة أستيبه

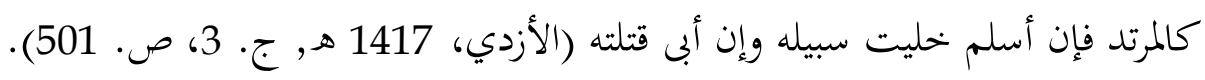

\section{ث. استتابة السب والشاتم كالاستتابة للمرتد}

قال القاضي عياض: إذا قلنا بالاستابة حيث تصح فالاختلاف على الاختلاف في توبة

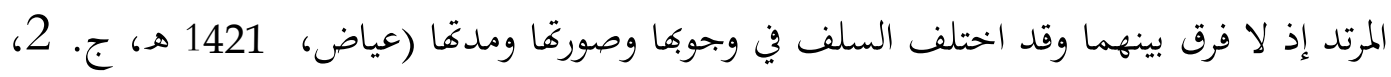
ص. 220).

في هذا الفصل ذكر القاضي عياض أقوال العلماء واختلافهم. أولا في ذكر الإستتابة

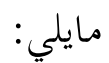

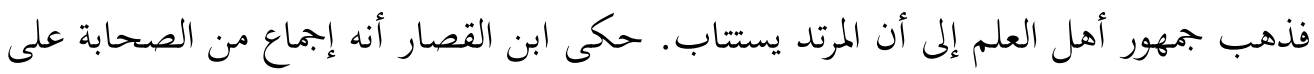

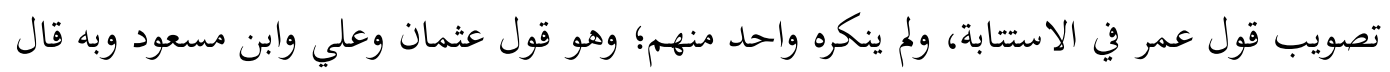

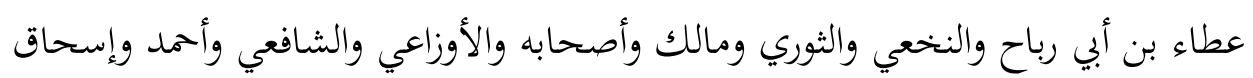

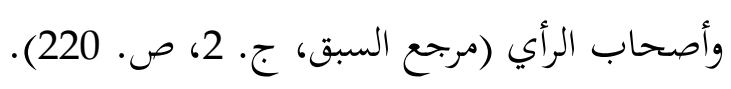

قال مالك: حدثني عن عبد الرممن بن محمد بن عبد الله بن بن عبد الله القارىء عن أبيه أنه قال :قدم على عمر بن الخطاب رجل من قبل أبي موسى الأشعري، فسأله عن الناس فأخبره ثم قال له له عاله

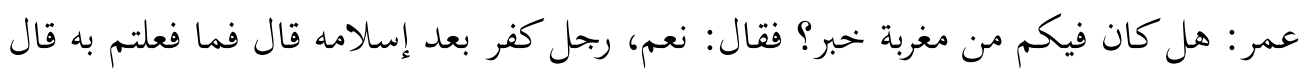

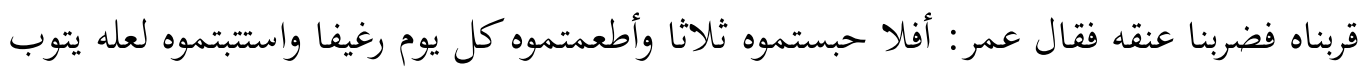

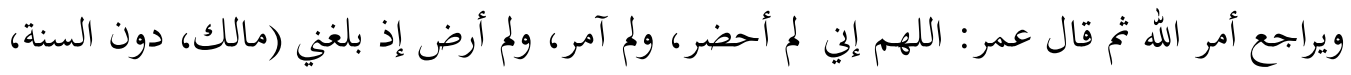
رقم: 1414، ج. 2، ص. 737 (737). وقال أيضا: فتبري عمر من فعلهم يقتضي وجوب الإمهال ثلاثة أيام قبل موت المرتد، فإن

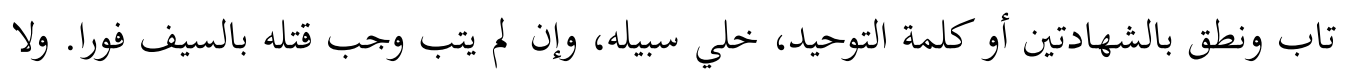

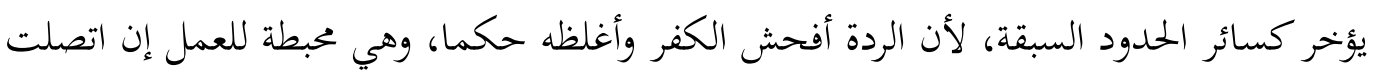

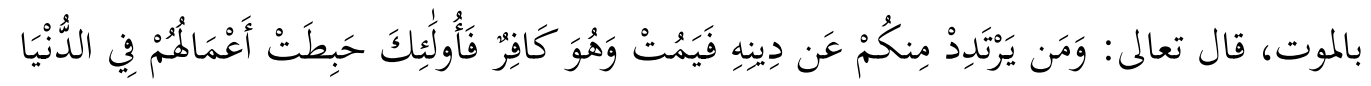

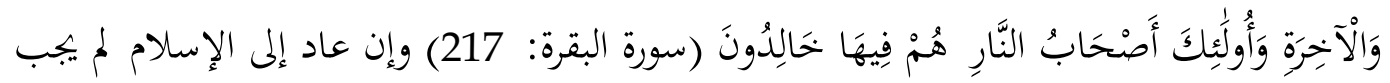

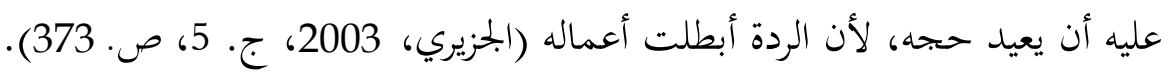

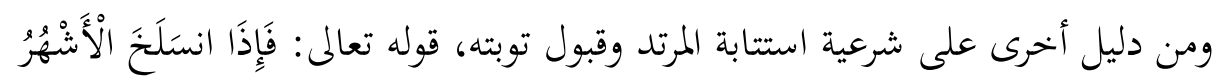

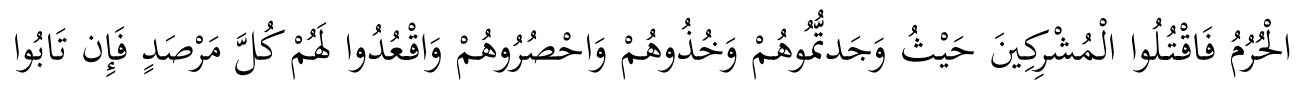




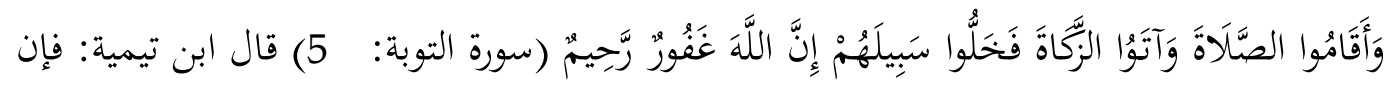

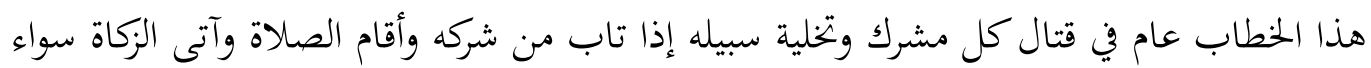

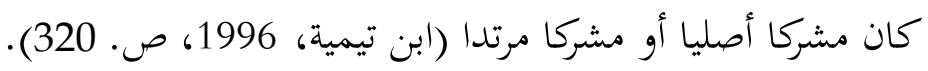
وخحلاف على ذلك، يعني ما ذهب طاوس وعبيد بن عمير والحسن في إحدى الروايتين عنه

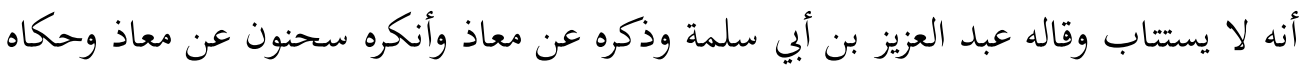

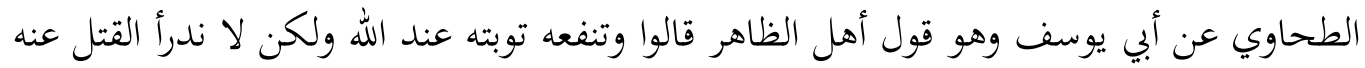

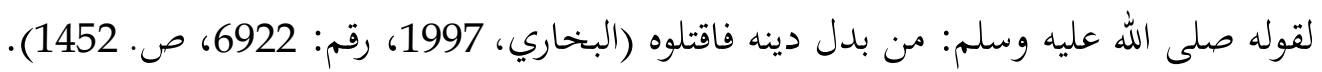

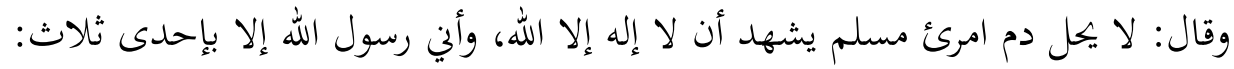
الثيب الزاني والنفس بالنفس والتارك لدينه المفارق للجماعة (مسلم ، 1998، رقم: 4375, ص.

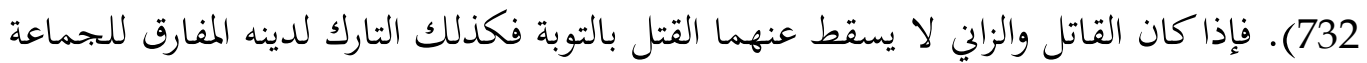

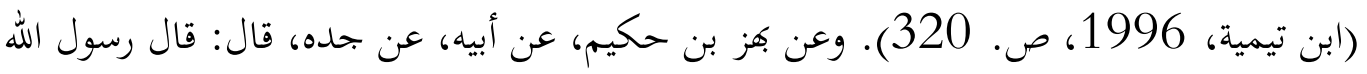

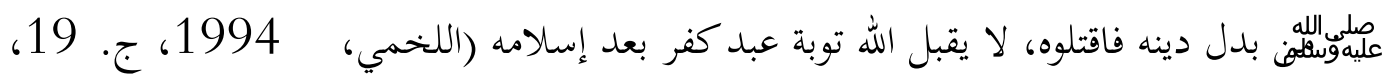

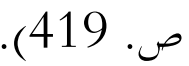

وحكي عن عطاء أنه إن كان من ولد في الإسلام ملم يستب ويستتاب الإسلامي (عياض،

$$
\text { 1421, ج. 2، ص. 220). }
$$

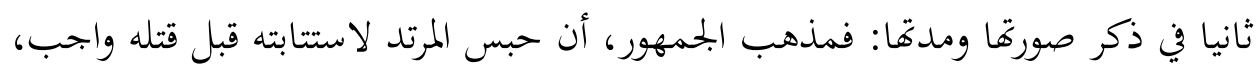

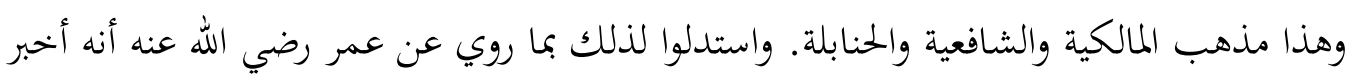

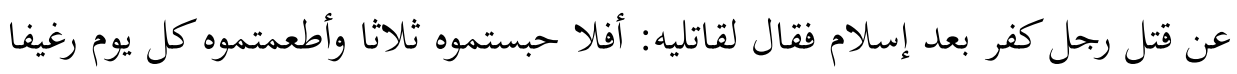

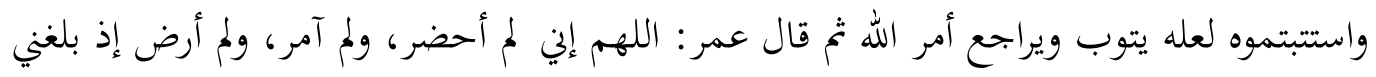

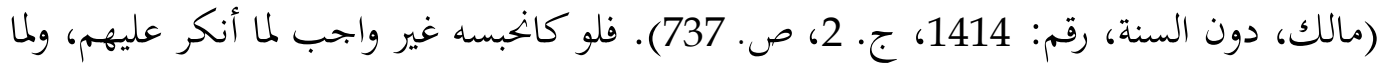

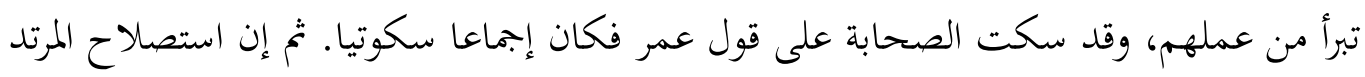

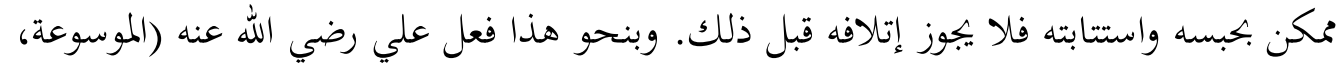
1427 هـ، ج. 16، ص. 300).

ومذهب الجمهور كما وروي عن عمرأنه يستتاب ثلاثة أيام، وأحد قولي الشافعي، (مالك، هاك،

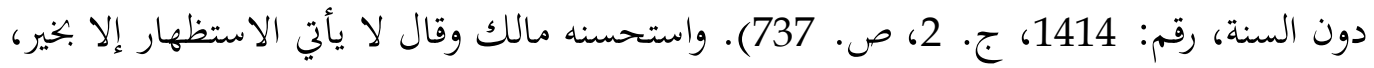


وهو قول أحمد وإسحاق، وقال مالك أيضا: الذي آحذ به في المرتد قول عمر: يحبس ثلاثة أيام ويعرض عليه كل يوم فإن تاب وإلا قتل (السبكي، 2000، ص. 216).

وخلاف على ذالك، ما ذهب الحنفية، والمنقول عن الحسن البصري وطاوس، وبه قال بعض المالكية: أن حبس المرتد لاستتابته قبل قتله مستحب لا واجب لحديث: من بدل دينه فاقتلوه

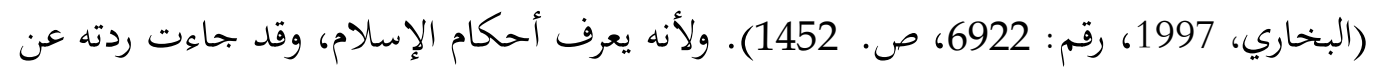
تصميم وقصد، ومن كان كذلك فلا يجب حبسه لاستتابته بل يستحب طمعا في رجوعه الموهوم (الموسوعة، 1427 هـ، ج. 16، ص. 300).

ثم ذكر القاضي عياض استحسان العلمآء وأقوالهم في مسألة مدة الإستتابة، أنه قال: استحسن الاستتابةَ والاستيناءَ ثلاثا أصحابُ الرأي، وروي عن أبي بكر الصديق أنه استتاب امرأة فلم نتب فقتلها، وقاله الشافعي مرة، فقال: إن لم يتب قتل مكانه، واستحسنه المزي. وقال الزهري يدعى إلى الإسلام ثلاث مرات فإن أبى قتل، وروي عن علي رضي الله عنه يستتاب شهرين، وقال

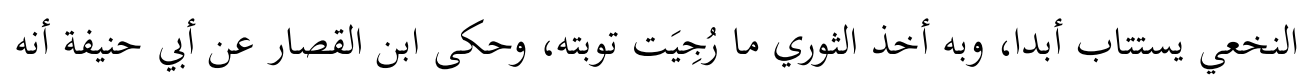

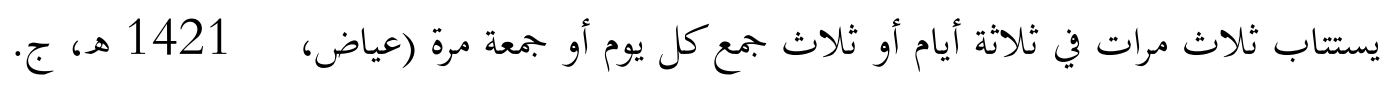
2. 221. 20. وقال القاضي عياض: واختلف على هذا هل يهلد أو يشدد عليه أيام الاستتابة ليتوب أم

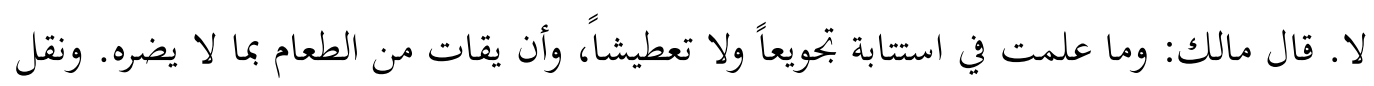

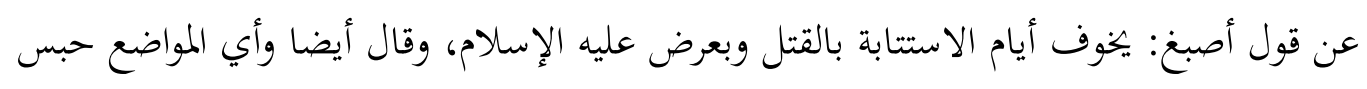
فيها من السجون مع الناس أو وحده إذا استوثق منه سواء ويوقف ماله إذا خيف أن يتلفه على إلى بلى المسلمين ويطعم منه ويسقى (مرجع السبق، ج. 2، ص. 221).

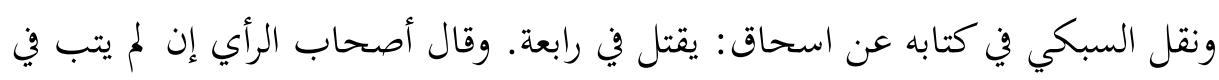
الرابعة قتل دون استتابة وإن تاب ضرب ضربا وجيعا ولم يخرج من السجن حتى يظهر عليه خشوع التوبة (السبكي، 2000، ص. 216).

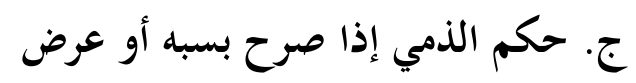

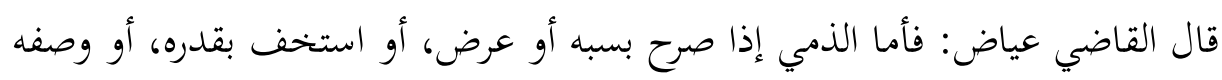
بغير الوجه الذي كفر به، فلا خلاف عندنا في قتله إن لم يسلم؛ لأنا لم نعطه الذمة أو العهد على بلى بلى إصلى 
هذا؛ وهو قول عامة الفقهاء، إلا أبا حنيفة والثوري وأتباعهما من أهل الكوفة فإنهم قالوا: لا يقتل؛

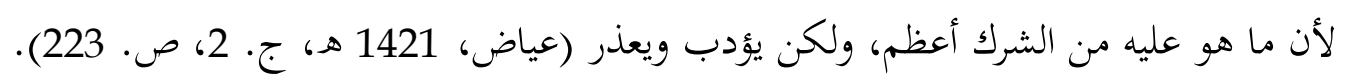

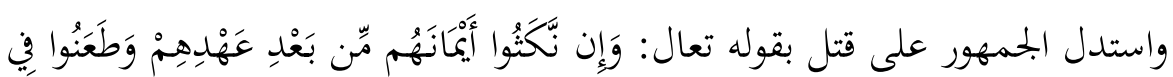

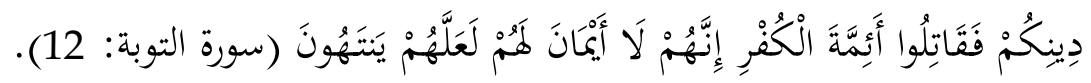

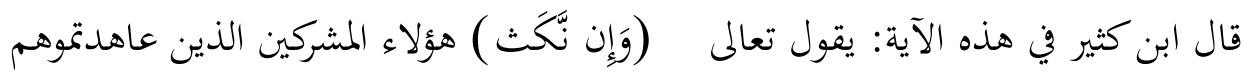

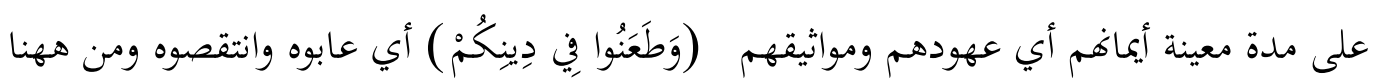

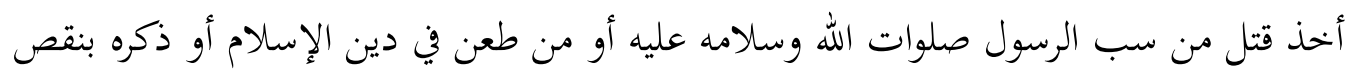

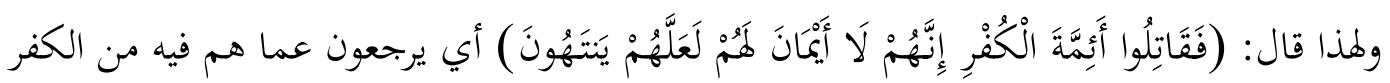

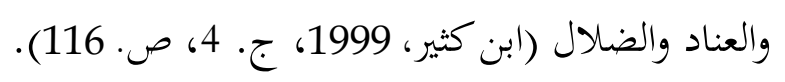

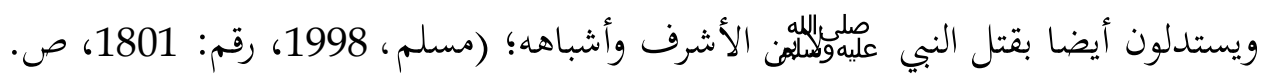

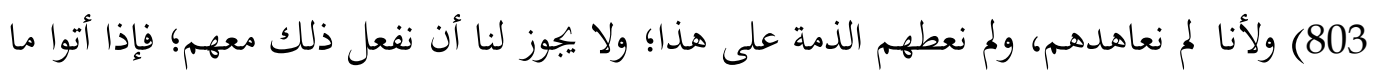

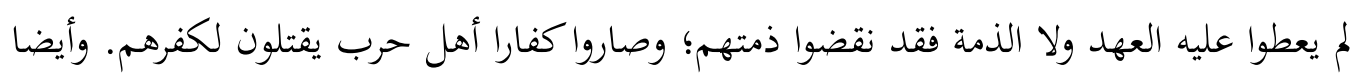

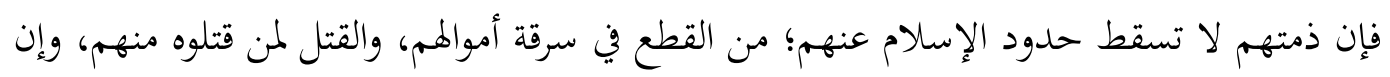

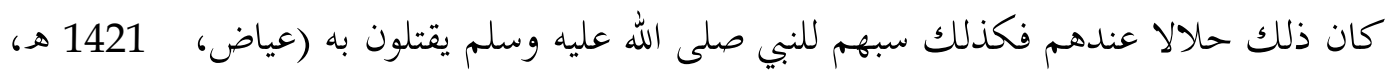
ج. 2، ص. 223). وفي نقل كلام العلماء في قتله ما يلي:

نقل عن ابن القاسم أنه قال: ومن شتم النبي صلى الله عليه وسلم من أهل الكت الكتاب قتل

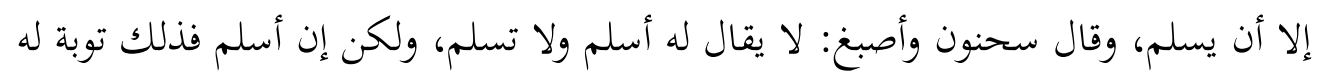

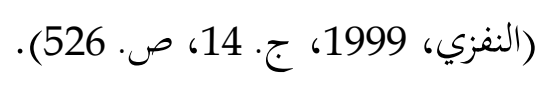

نقل شيخ الإسلام ابن تيمية قولا للإمام أحمد رممه الله فقال: قال الإمام أحمد في رواية

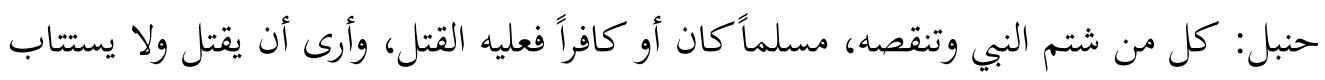

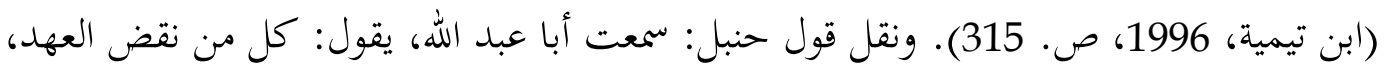

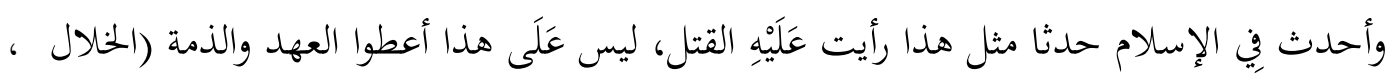

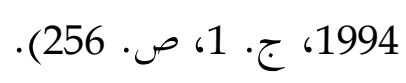


وكذالك نقل قول أبي الصقر وهو أصحاب الإمام أمد : سألت أبا عبد الله عن رجل من

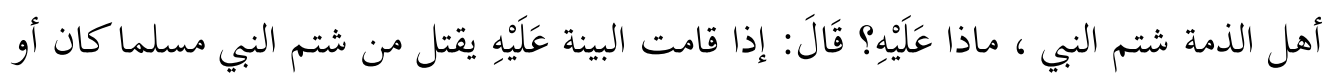

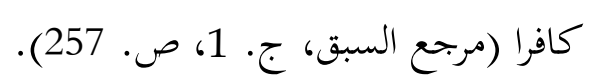

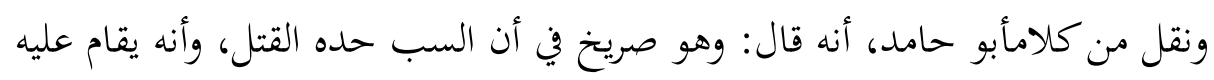

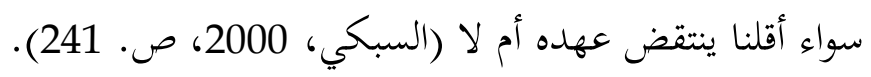
وأما سفيان الثوري، وأبو حنيفة، وأصحابه قالو : إن سب الذمي الله تعالى أو رسوله بأي

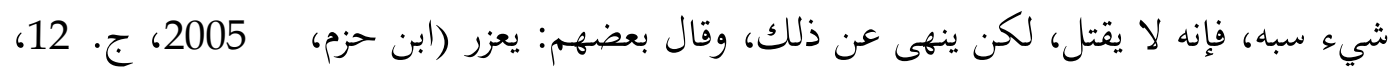

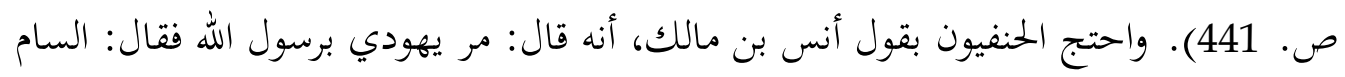

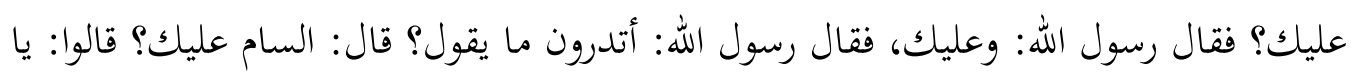

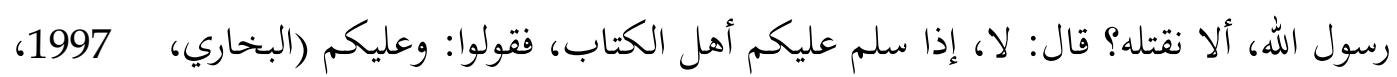
رقم: 6926، ص. 1453). وعن عائشة قالت: استأذن رهط من اليهود على النبي، فقالوا: السام عليك، فقلت: بلى، اليكا،

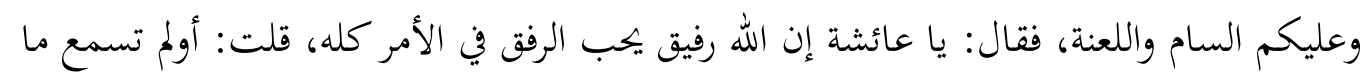

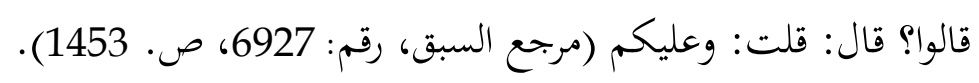

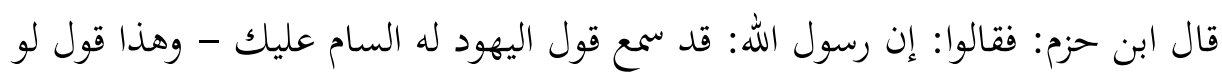

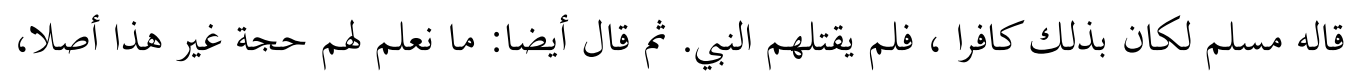

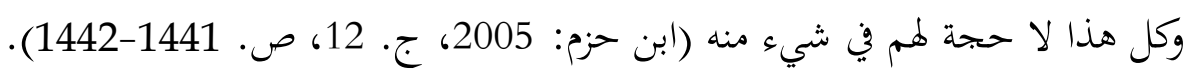

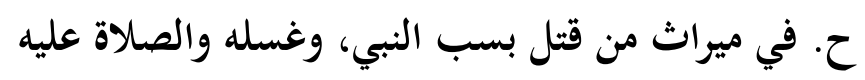

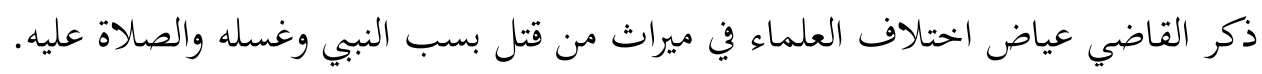

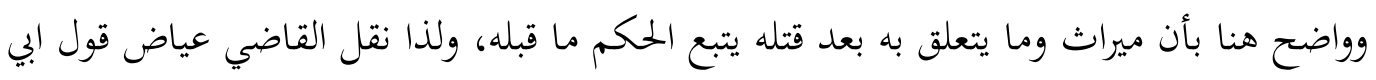

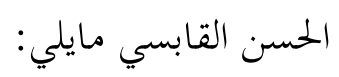
قال أبو الحسن القابسي: إن قتل وهو منكر للشهادة عليه فالحكم في ميراثه على ما أظهر

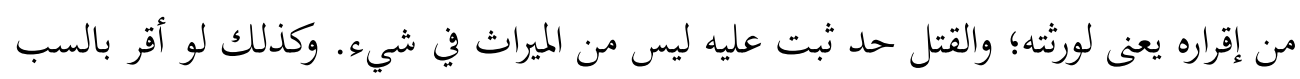

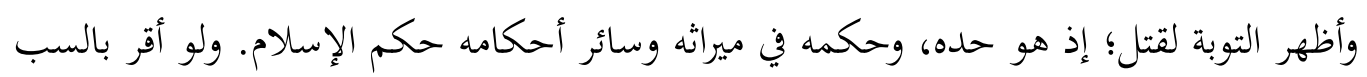

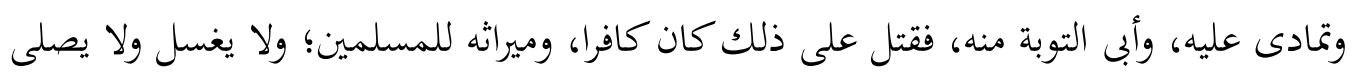


عليه، ولا يكفن وتستر عورته، ويوارى كما يفعل بالكفار. وفي المحاهر المتمادى بين لا يمكن الخلاف فيه لأنه كافر مرتد غير تائب ولا مقلع (عياض، 1421 هـ، ج. 2، ص. 277). قال القاضي عياض: وتفصيل أبى الحسن في باقى جوابه حسن بين وهو على رأى أصبغ وخلاف قول سحنون واختلافهما على قولي مالك في ميراث الزنديق فمرة ورثه ورثته من المسلمين قامت عليه بذلك بينة فأنكرها أو اعترف بذلك وأظهر التوبة. (مرجع السبق، ج. 2، ص. 228). وأما ميراث المرتد عند العلماء مايلي: قال أبو حنيفة والثوري ما اكتسبه قبل الردة فهو لورثثه من المسلمين وما اكتسبه بعد الردة فهو فيء، وقال ابن شبرمة وأبو يوسف ومحمد والأوزاعي في إحدى الروايتين ما اكتسبه قبل الردة وبعدها فهو لورثته من المسلمين (الأزدي، 1987، ج. 4، ص. (596) قال مالك: يوقف ماله أبدا حتى يعرف أنه مات، فإن رجع إلى الإسلام كان أولى بماله، وإن مات على ارتداده كان ذلك لجميع المسملين ولا يكون لورثته (مالك، 1994، ج. 2. .$(596$

قال الشافعي: كل ما اكتسب المرتد في ردته أو كان له قبل الردة سواء وهو فيء؛ لأن الله تبارك وتعالى منع الدماء بالإسلام ومنع الأموال بالذي منع به الدماء، فإذا خرج الرجل من الإسلام إلى أن يباح دمه بالكفر كما كان يكون مباحا قبل أن يسلم يباح معه ماله وكان أهون من دمه لأنه كان ممنوعا تبعا لدمه، فلما هتكت حرمة الدم كانت حرمة المال أهتك وأيسر من الدم وليس قتلنا إياه على الردة كقتلنا إياه على الزنا ولا القتل ولا المحاربة تلك حدود لسنا نخرجه بها من أحكام الإسلام وهو فيها وارث موروث كما كان قبل أن يحدثها وليس هكذا المرتد: المرتد يعود دمه مباحا بالقول بالشرك (الشافعي، 1990، ج. 7، صن. قال أحمد بن حنبل: المرتد لا يرثه ورثته لأنه يقتل على الكفر وليس اختلاف أن المسلم لا

$$
\text { يرث الكافر (الشيباني، دون السنة، ج. 3، ص. 131). }
$$

الخاتمة

أحمد الله تعالى الرازق المنان القادر على كل شيئ، بنعمته وعنايته تمت كتابة هذ البحث. أرجو من قرآ بعض التقويمات والإصلاحات من كل خطأ وجد، و يرجو الباحث من الله فضله وثوابه و أن يعذربي من الزلات في هذ البحث وأن ينفع به الأمة إلى يوم القيامة. ووفي هذا المحال سيقوم الباحث بالتلخيص مماكتب في الأبواب القديمة مايلي: 
أولا: أن السب هو الكلام الذي يقصد به الانتقاص والاستخفاف، وهو ما يفهم منه السبّ في عقول الناس على اختلاف اعتقاداتمكاللعن والتقبيح ونحوه. و أن جميع من سبّ النبي أو عابه أو ألحق به نقصا في نفسه أو نسبه أو دينه أو خصلة من خصاله أو عرض به أو شبهة بشئ على طريق السب له أو الإزراء عليه أو التصغير لشأنه أو الغض منه والعيب له فهو سب له. ثانيا: الفرق بين السب و بين الإستزاء: بأن السب يشبهالاستهزاء بل أشد إثما وشناعة واستكبارا على رب العالمين، وهو كفر من باب أولى من الاستهزاء. وأن أدلة في حكم الاستهزاء هي نفس أدلة حكم السب.

ثالثا: اتفق العلماء أن سب النبي يجعل صاحبه مخرج من الإسلام، وأن عقوبته القتل.

ولكن اختلفوا في صفة القتل؛ رأى الحنفيه و الشافعية في أصح قتله بسبب المرتد لا حدا و إما المالكية والحنابلة رأوا بأن قتله حدا لا كفرا. وأما الذمي اذا سب النبي، رأى الجمهور على قتله لنقض عهده حلافا للحنفية أنه قال بتعزيره لأن رسول الله لم يقل يقتل يهود الذي قال له: السام عليكم. ولكن اختلف العلمآء على قتله ان كان يدخل في دين الإسلام. رابعا: وأما استتابة سب الرسول فرأى الحنفية والشافعية أنه يستتاب وأما المالكية والحنابة رأوا بأنه لا يستتاب، لأن الحد لا يسقط بالتوبة. خامسا: وأما الميراث من قتل بسب النبي وغسله والصلاة عليه وما يتعلق به بعد قتله يتبع الحلكم ما قبله. إن قتل وهو منكر للشهادة عليه فالحكم في ميراثه على ما أظهر من إقراره يعنى لورثثه، و كذالك إن أظهر توبته عنه. ولو أقر بالسب وتمادى عليه، وأبى التوبة منه، فقتل على ذلك كان كافرا، وميراثه للمسلمين؛ ولا يغسل ولا يصلى عليه، ولا يكفن، ولا يوارى إلا كما يفعل بالكفار .

\section{مصادر البحث}

ابن تيمية، أحمد بن عبد الحليم.1996. الصارم المسلول على شاتم الرسول بيروت: دار الكتاب العربي.

ابن حزم، علي بن أحمد بن سعيد. 2005.المحلى. القاهرة: مكتبة دار التراث. ابن عابدين، محمد أمين بن عمر. 1992. رد المحتار على الدر المختار. بيروت: دار الفكر. ابن عبد البار. 1387. التمهيد. المغرب: وزارة عموم الأوقاف والشؤون الإسلامية. ابن فرحون المالكي، الديباح المذهب في معرفة أعيان علماء المذهب. القاهرة: دار التراث. 
ابن كثير القرشي، إسماعيل بن عمر. 1999. تفسير القرآن العظيم. دار طيبة للنشر والتوزيع.

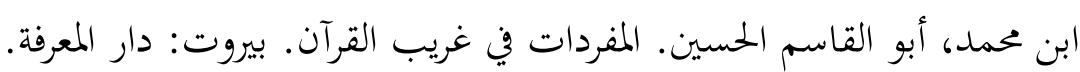
الأزدي، أحمد بن محمد بن سلامة. 1417 هـ. مختصر اختلاف العلماء. بيروت: دار البشائر الإسلامية. الأزدي، محمد بن الحسن بن دريد. 1987. جمهرة اللغة. بيروت: دار العلم للملايين.

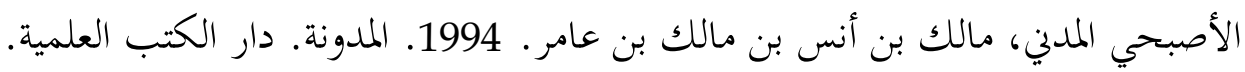

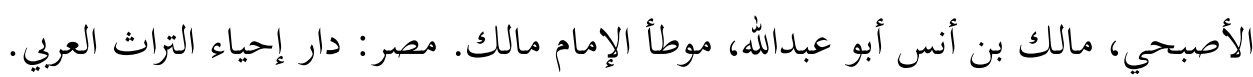

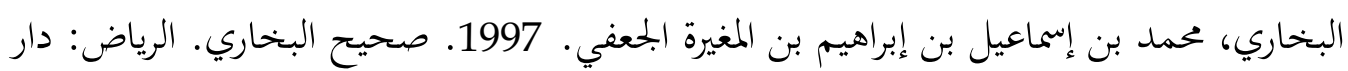
السلام.

الجزيري، عبد الرحمن بن محمد عوض. 2003. الفقه على المذاهب الأربعة. بيروت : دار الكتب الب

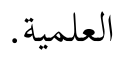

الحفاجي، أحمد بن محمد بن عمر. 2001. نسيم الرياض في شرح شفاء القاضي عياض. بيروت: دار الكتب العلمية.

الخَلَّلا، أحمد بن محمد بن هارون بن يزيد. 1994. أحكام أهل الملل والردة من الجامع لمسائل الإمام أحمد بن حنبل. بيروت : دار الكتب العلمية. الدمشقي، محمد بن أمين بن عمر بن عبد العزيز . تنبيه الولاة والحكام على أحكام شاتم خير الأنام

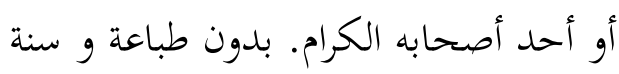
السبكي الشافعي، علي بن عبد الكافي. 2000. السيف المسلول على من سب الرسول. بيروت: دار سنه الفتح للشر. السبكي، علي بن عبد الكافي. فتاوى السبكي. بيروت: دار المعرفة.

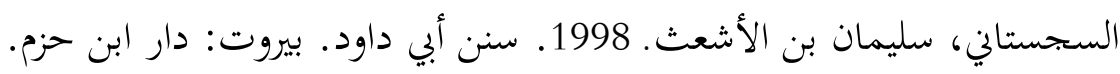
الشافعي، محمد بن إدريس. 1990. الأم. بيروت: دار المعرفة.

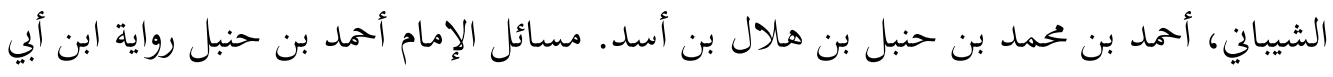
الفضل صالح. الهند: الدار العلمية. العسقلاني، أحمد بن علي بن حجر. فتح الباري. دار الفكر.

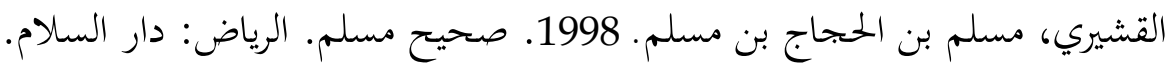


أحكام سب الرسول عند القاضي عياض في كتابه

$$
\text { قطب، محمد، واقعنا المعاصر. 1997. بيروت: دار الشروق. }
$$

اللخمي، سليمان بن أحمد بن أيوب بن مطير. 1994. المعجم الكبير. الرياض: بـواض: دار الصميعي.

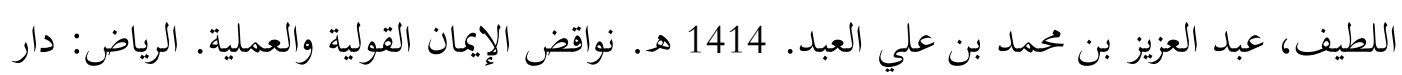

$$
\begin{aligned}
& \text { الوطن. } \\
& \text { المصري، أبو عبدالرحمان. 2006. تخذير المسلمين من السب و الاستهزاء بالدين. ملتقى أهل } \\
& \text { الحديث. } \\
& \text { المنجد في اللغة و الأعلام. 1973. بيروت: دار المشرق. }
\end{aligned}
$$

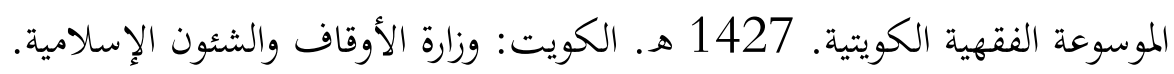

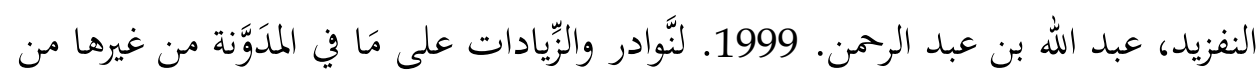

$$
\begin{aligned}
& \text { الأُمهاتِ. بيروت: دار الغرب الإسلامي. }
\end{aligned}
$$

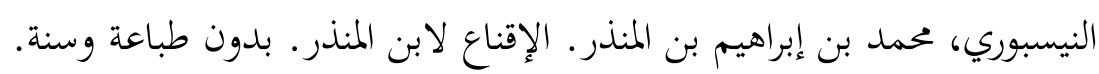

$$
\begin{aligned}
& \text { اليحصبي، عياض بن موسى بن عياض. } 1421 \text { هـ. كتاب الشفا بتعريف حقوق المصطفى. بيروت: } \\
& \text { دار الفكر }
\end{aligned}
$$




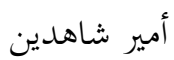

Halaman ini sengaja dikosongkan 